\title{
BDNF Overexpression in the Forebrain Rescues Huntington's Disease Phenotypes in YAC128 Mice
}

\author{
Yuxiang Xie, ${ }^{1}$ Michael R. Hayden, ${ }^{2}$ and Baoji Xu${ }^{1}$ \\ ${ }^{1}$ Department of Pharmacology, Georgetown University Medical Center, Washington, DC 20057, and ${ }^{2}$ Centre for Molecular Medicine and Therapeutics, \\ Child and Family Research Institute, University of British Columbia, Vancouver, British Columbia V5Z 4H4, Canada
}

\begin{abstract}
Huntington's disease (HD) is caused by an expansion of the polyglutamine tract at the $\mathrm{N}$ terminus of huntingtin. This mutation reduces levels of BDNF in the striatum, likely by inhibiting cortical $B d n f$ gene expression and anterograde transport of BDNF from the cerebral cortex to the striatum. Substantial evidence suggests that this reduction of striatal BDNF plays a crucial role in HD pathogenesis. Here we report that overexpression of BDNF in the forebrain rescues many disease phenotypes in YAC128 mice that express a full-length human huntingtin mutant with a 128-glutamine tract. The $B d n f$ transgene, under the control of the promoter for $\alpha$ subunit of $\mathrm{Ca}^{2+} / \mathrm{calmodulin}^{-}$ dependent protein kinase II, greatly increased BDNF levels in the cerebral cortex and striatum. BDNF overexpression in YAC128 mice prevented loss and atrophy of striatal neurons and motor dysfunction, normalized expression of the striatal dopamine receptor D2 and enkephalin, and improved procedural learning. Furthermore, quantitative analyses of Golgi-impregnated neurons revealed a decreased spine density and abnormal spine morphology in striatal neurons of YAC128 mice, which was also reversed by increasing BDNF levels in the striatum. These results demonstrate that reduced striatal BDNF plays a crucial role in the HD pathogenesis and suggest that attempts to restore striatal BDNF level may have therapeutic effects to the disease.
\end{abstract}

\section{Introduction}

Huntington's disease (HD) is a neurodegenerative disease involving severe motor dysfunction, cognitive deficits, and psychiatric difficulties. It is caused by an expansion of CAG trinucleotide repeats in the gene for huntingtin. The marked atrophy of the striatum seen in HD patients is mostly due to massive loss of medium-sized spiny neurons (MSNs) (Vonsattel and DiFiglia, 1998). While the mechanism by which mutant huntingtin leads to this selective degeneration of striatal neurons remains to be elucidated, increasing attention has been given to reduced levels of BDNF in the striatum of HD patients.

A significant reduction in levels of striatal BDNF has been reported in both HD patients (Ferrer et al., 2000) and HD mice (Spires et al., 2004a; Gharami et al., 2008). Mutant huntingtin reduces levels of BDNF in the striatum likely by inhibiting cortical Bdnf gene expression (Zuccato et al., 2001, 2003) and anterograde transport of BDNF from the cortex to the striatum (Gauthier et al., 2004; Her and Goldstein, 2008). BDNF is required for the survival and differentiation of striatal neurons (Mizuno et al., 1994; Ventimiglia et al., 1995; Ivkovic and Ehrlich, 1999; Baquet et al., 2004), and a deficiency in BDNF-mediated signaling alone is sufficient to cause dendritic abnormalities and neuronal loss in the cerebral cortex and striatum (Xu et al., 2000; Baquet et al., 2004). These observations raise the possibility that

Received March 30, 2010; revised Sept. 8, 2010; accepted Sept. 15, 2010

This work was supported by a grant from the National Institutes of Health (NS050596). We thank Dr. Susumu Tonegawa at the Massachusetts Institute of Technology for Bdnf transgenic mice.

Correspondence should be addressed to Dr. Baoji Xu, Department of Pharmacology, Georgetown University, 3900 Reservoir Road NW, Washington, DC 20057. E-mail: bx3@georgetown.edu.

DOI:10.1523/JNEUROSCI.1637-10.2010

Copyright $\odot 2010$ the authors $\quad 0270-6474 / 10 / 3014708-11 \$ 15.00 / 0$ the reduced supply of striatal BDNF may significantly contribute to HD pathogenesis. In support of this view, the progression of Huntington's disease is accelerated in $B d n f$ heterozygous mice (Canals et al., 2004; Pineda et al., 2005; Giralt et al., 2009). Furthermore, alterations of gene expression profile in the striatum have been shown to be similar in HD patients and mice in which the $B d n f$ gene is deleted in the cerebral cortex (Strand et al., 2007). In light of these findings, efforts have been made to test whether increasing BDNF expression represents a valuable strategy for treatment of Huntington's disease. Indeed, increasing striatal BDNF levels by a transgene (Gharami et al., 2008), viral delivery (Cho et al., 2007), or stimulations that induce $B d n f$ gene expression (Spires et al., 2004a; Peng et al., 2008; Simmons et al., 2009) have been shown to improve disease phenotypes in R6/1 or R6/2 mice that express an $\mathrm{N}$-terminal fragment of mutant huntingtin (Mangiarini et al., 1996).

We have previously shown that BDNF overexpression in the forebrain ameliorated motor dysfunction, reversed brain weight loss, normalized expression of some genes, and reduced formation of neuronal intranuclear inclusions in R6/1 mice (Gharami et al., 2008). Here we report that BDNF overexpression in the forebrain rescues many disease phenotypes in YAC128 mice, a more physiological HD mouse model that expresses the whole human huntingtin gene with 128 CAG repeats and exhibits agedependent loss of striatal neurons (Slow et al., 2003).

\section{Materials and Methods}

Animals. YAC128 mice (Slow et al., 2003) and Bdnf transgenic (BTg) mice (Huang et al., 1999) were previously described. Both mouse strains were maintained on the C57BL/6 background. YAC128 mice were crossed to BTg mice to produce wild-type (WT), YAC128, BTg, and YAC128;BTg double transgenic (YAC;BTg) mice. Each mouse was 
A

WT

YAC128

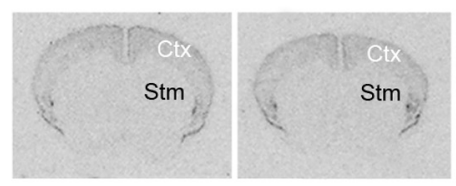

B

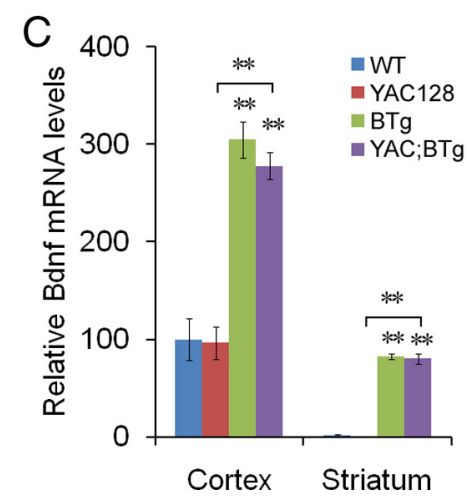

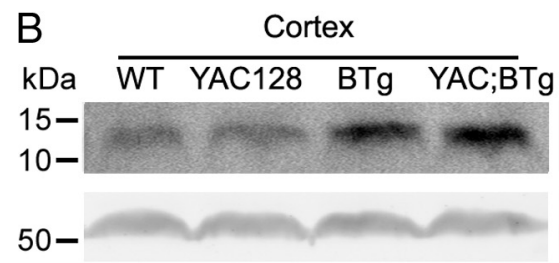

$\mathrm{BTg}$
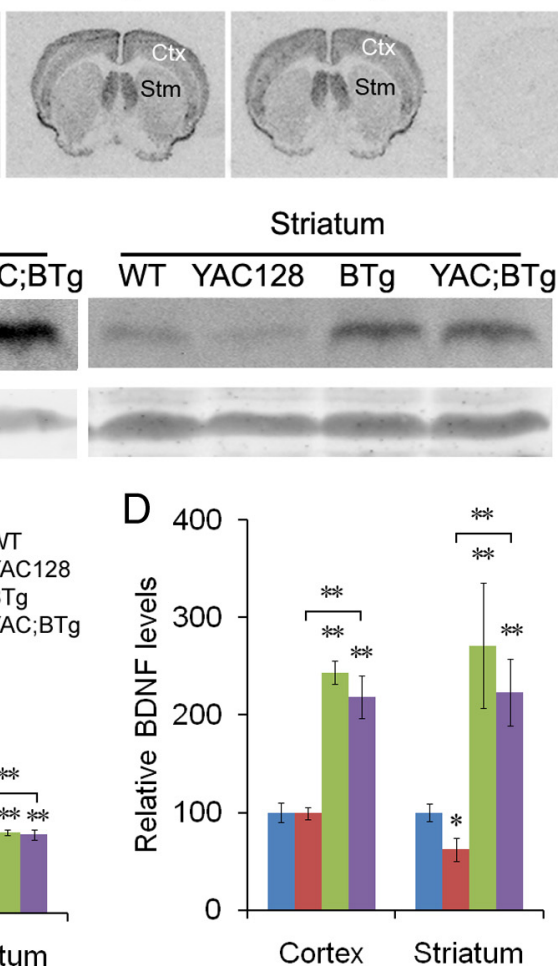

Figure 1. Cortical and striatal levels of Bdnf mRNA and mature BDNF protein in YAC128 and BTg mice. $A$, Representative in situ hybridization images showing levels of $B d n f m R N A$ in brains of WT, YAC128, BTg, and YAC;BTg mice. The probes were ${ }^{35} S$-labeled antisense and sense RNAs corresponding to the $B d n f$ coding region. $\boldsymbol{B}$, Representative Western blots showing levels of mature BDNF protein in the cerebral cortex and striatum. C, Quantification of $B d n f$ in situ hybridization signals in the cerebral cortex and striatum. The optical density of signals was measured on eight sections for each mouse (cortex: $F_{(3,12)}=38.1, p<0.0001$; striatum: $F_{(3,12)}=401.3, p<0.0001 ; n=4-5$ mice/genotype). $D$, Relative levels of mature BDNF in the cerebral cortex and striatum, as revealed by Western blots (cortex: $F_{(3,14)}=80.89, p<0.0001$; striatum: $F_{(3,20)}=6.997, p<0.001 ; n=4-6$ mice/genotype). Error bars represent SEs. Multiple comparisons using $t$ test: ${ }^{*} p<0.05 ;{ }^{* *} p<0.01$.

marked with an ear tag. The Bdnftransgene was identified by Southern blots, and the YAC128 transgene was identified by PCRs using two sets of primers (RYA primers: 5' -CTTGAGATCGGGCGTTCGACTCGC- 3 ' and 5' -CCGCACCTGTGGCGCCGGTGATGC-3'; LYA primers: 5'-CCTGCTCGCTTCGCTACTTGGAGC- $3^{\prime}$ and $5^{\prime}$-GTCTTGCGCCTTAAACCAACTTGG$3^{\prime}$ ). The observer was blind to the genotypes of the mice during all behavioral tests. All animal procedures were approved by the Georgetown University Animal Care and Use Committee.

Rotarod tests. Motor coordination was tested using a rotarod apparatus (Ugo Basile). To document changes in locomotor ability over time, we performed the rotarod test at three time points based on a previous report (Van Raamsdonk et al., 2005): early stage (4 month) when YAC128 mice show no evidence of abnormal behavior, middle stage ( 9 months) which corresponds to the onset of brain atrophy, and late stage (16 months) when animals display serious hypokinesis. Mice were weighted and trained for three consecutive days, and there were three trials with a one-h interval each day. Mice were placed on a rotating rod that accelerated from 4 to $40 \mathrm{rpm}$ in $5 \mathrm{~min}$. The time mice stayed on the rotating rod was recorded. If mice stayed on the rotating rod for $5 \mathrm{~min}$ or longer, a score of $300 \mathrm{~s}$ was recorded. The best score on the third day was used for analysis.

Beam walk test. One week after completion of rotarod tests, beam walk tests were performed using a homemade setup. The mice were trained for 3 consecutive days ( 3 training sessions per day) to traverse a round wood beam with a diameter of $15 \mathrm{~mm}$. The latency to traverse the $90 \mathrm{~cm}$ beam was recorded for each trial. Beam walk assays were quantified according to a previous study (Liu et al., 2009). For mice that did not move within $3 \mathrm{~min}$ (freeze) or fell off the beam (fall), a maximum latency score of $30 \mathrm{~s}$ was given. For each mouse, the best score of the three trials on the last day was used for analysis.
BDNF

Tubulin

Footprint measurement. The hindpaws of mice were coated with nontoxic paints. The mice were trained to walk along a dark tunnel $(50 \mathrm{~cm}$ long, $8 \mathrm{~cm}$ wide, and $12 \mathrm{~cm}$ high), and a fresh sheet of white paper was placed on the floor of the runway for each run. The first few strides were discarded, and stride length and base width were measured for 4 continuous strides.

Muscle strength. The grip strength apparatus is comprised of a triangle wire knob $(6 \mathrm{~cm}$ wide) connected to a balance scale. We lifted a mouse by the tail so that its forepaws could grasp the wire. The mouse was then gently pulled backward by the tail until the wire was released. The maximal force exerted before the mouse lost the grip was recorded. Each mouse was tested for nine trials, and the average of three highest scores was used for subsequent analysis.

Simple swimming test of procedural learning. A simple swimming test was conducted as described previously (Van Raamsdonk et al., 2005). Briefly, mice were placed in the middle of a linear swimming chamber $(58 \times 23 \mathrm{~cm}$; water depth, $9 \mathrm{~cm}$; platform, $4 \times 11.5 \mathrm{~cm}$ ) facing away from the escape platform. The amount of time required for mice to reach the platform and the initial swimming direction were recorded for each trial. Swimming toward the platform was arbitrarily given a score of 0 , whereas swimming away from the platform was given a score of 1 . Mice were trained for $3 \mathrm{~d}$ with three pairs of two consecutive trials spaced $2 \mathrm{~h}$ per day. For each mouse, the average of the three trials on the last day was used for analysis.

In situ hybridization. In situ hybridization was performed as described previously (Xu et al., 2003). In brief, mouse brains were dissected and frozen immediately in an isopentane-dry ice bath. All in situ hybridization was performed on cryostat coronal sections at $10 \mu \mathrm{m}$, using ${ }^{35} \mathrm{~S}$-labeled antisense or sense riboprobes derived from cDNA sequences for $B d n f$ mRNA (the whole coding region), Drdla mRNA (encoding dopamine receptor D1a; GenBank accession number NM_010076, nucleotides 896-1337), Drd2 mRNA (encoding dopamine receptor D2; GenBank accession number NM_010077, nucleotides 551-1350), Penk mRNA (encoding the enkephalin precursor, preproenkephalin; GenBank accession number NM_001002927, nucleotides 301-800), and Tac1 mRNA (encoding the substance P precursor, tachykinin 1; GenBank accession number NM_009311, nucleotides 50-540). After hybridization and washes, sections were exposed to Kodak BioMax MR Hyperfilm. For each mouse, images from eight sections were scanned at $1200 \mathrm{dpi}$, and the optical density of in situ signal in the dorsolateral area of the striatum was determined using NIH ImageJ. After background subtraction, the mean optical density of a brain region was used for analysis.

Immunoblotting. Dissected cortical and striatal tissues were homogenized in a lysis buffer ( 80 mm Tris-Cl, 2\% SDS, $10 \%$ glycerol, $\mathrm{pH} 6.8$ ) and centrifuged at 12,500 rpm for $30 \mathrm{~min}$. Protein concentrations of extracts were measured using the $D_{c}$ protein assay kit (Bio-Rad Laboratories). Extracts in a loading buffer were denatured for $5 \mathrm{~min}$ at $100^{\circ} \mathrm{C}$, separated on an SDS-PAGE gel, and transferred onto a polyvinylidene fluoride membrane. The membrane was blocked with Odyssey Blocking Buffer or $5 \%$ nonfat milk in TBS ( $10 \mathrm{~mm}$ Tris-Cl, $\mathrm{pH} 7.5,150 \mathrm{~mm} \mathrm{NaCl}$ ) for $1 \mathrm{~h}$ and then incubated with primary antibodies overnight at $4^{\circ} \mathrm{C}$. After two washes with TBST (10 mm Tris-Cl, pH 7.5, 150 mm NaCl, 0.5\% Tween 20 ), the membrane was incubated with appropriate IRDye secondary antibodies (LI-COR Biosciences) for $1 \mathrm{~h}$ at room temperature. The membrane was then washed three times with TBST, and proteins were visual- 

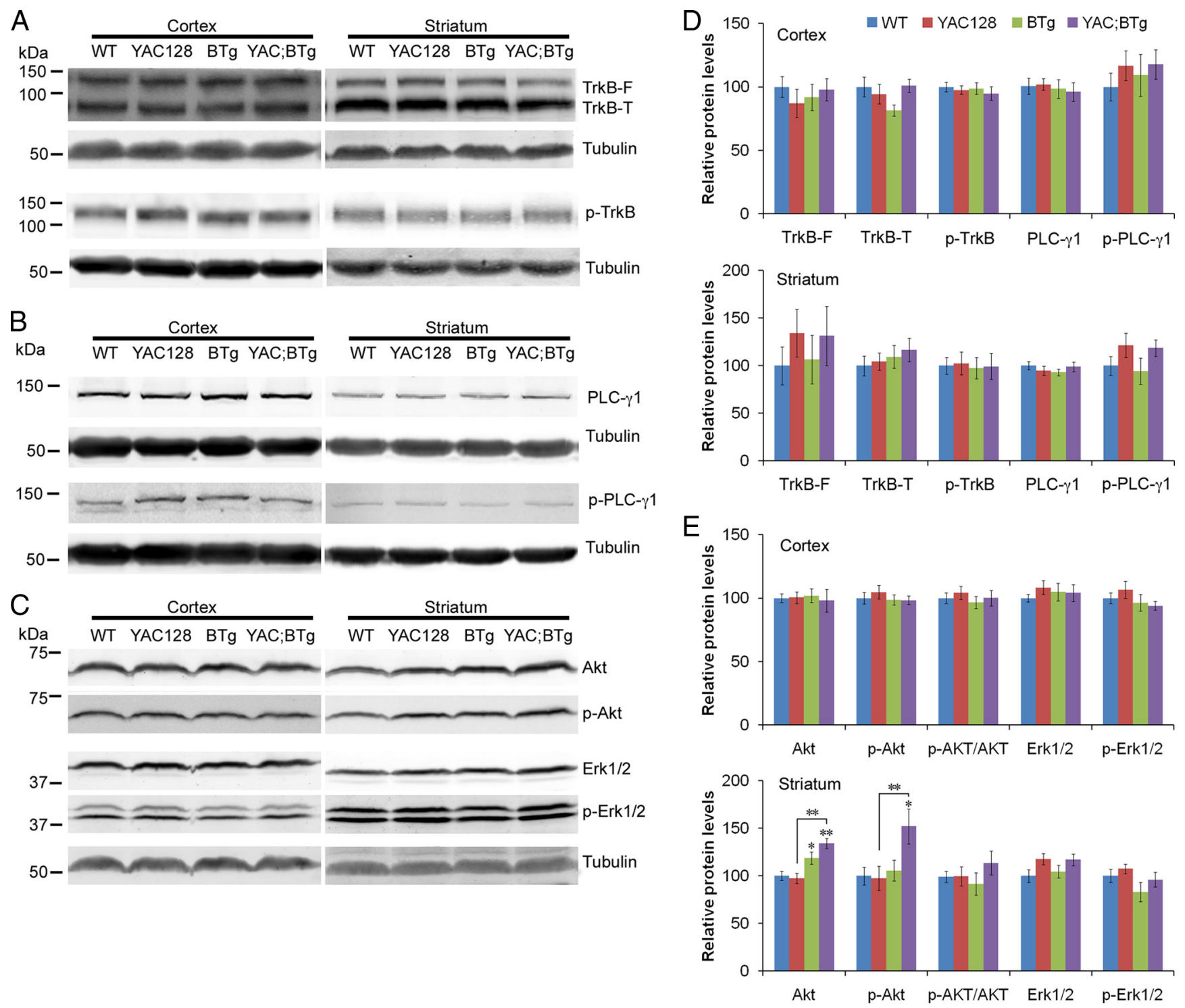

Figure 2. Activation of the TrkB receptor in YAC128 and BTg mice. $A-C$, Representative Western blots showing levels of TrkB receptors, downstream effectors (Akt, Erk1/2, and PLC- $\gamma 1$ ), and their activated (phosphorylated) forms (p-TrkB, p-Akt, $p$-Erk1/2, and p-PLC- $\gamma 1$ ) in the cortex and striatum. $\boldsymbol{D}, \boldsymbol{E}$, Relative levels of TrkB receptors and downstream effectors in the cortex and striatum $(n=$ 4-9 mice per genotype). One-way ANOVA analyses revealed that there was a significant effect of genotype on levels of striatal Akt $\left(F_{(3,23)}=9.609, p<0.001\right)$ and striatal p-Akt $\left(F_{(3,23)}=3.928\right.$, $p<0.05$ ), but not for other protein levels. Error bars represent SEs. Multiple comparisons using $t$ test: ${ }^{*} p<0.05$; ${ }^{* *} p<0.01$.

ized and quantified using the Odyssey Infrared Imaging System (LI-COR Biosciences). The membrane was then stripped and blotted with other antibodies. Intensity of each band was normalized to $\alpha$-tubulin. Antibodies used were from Santa Cruz Biotechnology (BDNF, sc-546, 1:500), Cell Signaling Technology (DARPP-32, Akt, phospho-Akt, Erk1/2, phospho-Erk1/2, PLC- $\gamma 1$, and phospho-PLC- $\gamma 1$, all of which were used at 1:1000 dilution), Epitomics (phospho-TrkB at Y817, 1:1000), and Sigma ( $\alpha$-tubulin, 1:7500). The antibody to TrkB was kindly provided by Dr. Louis Reichardt (University of California, San Francisco, CA).

Immunohistochemistry. Mice were anesthetized with avertin and transcardially perfused with PBS and 4\% paraformaldehyde sequentially. Brains were removed from the skull, postfixed in $4 \%$ paraformaldehyde overnight, and soaked in $30 \%$ sucrose. Coronal brain sections $(40 \mu \mathrm{m})$ were obtained with a sliding microtome, rinsed once with TBS, and incubated with $10 \%$ methanol-3\% hydrogen peroxide in TBS to quench endogenous peroxidase. After incubating with a blocking buffer $(0.4 \%$ Triton X-100, 2.5\% bovine serum albumin, and $10 \%$ horse serum in TBS) for $1 \mathrm{~h}$, the sections were incubated with a primary antibody diluted in the blocking buffer overnight at room temperature. After three washes in the blocking buffer, the sections were incubated with an appropriate biotinylated secondary antibody, followed by the avidin-biotin-peroxidase complex (Vector Laboratories) according to the instructions of the manufacturer. Sections were developed in $0.05 \%$ 3,3'-diaminobenzidine tetrahydrochloride and $0.003 \%$ hydrogen peroxide in $0.1 \mathrm{M}$ Tris- $\mathrm{Cl}, \mathrm{pH}$ 7.5 , mounted onto slides, dehydrated, and coverslipped with DPX.

Stereology. We used Stereo Investigator software (MicroBrightField Inc) to calculate striatal volume and neuronal numbers in the striatum. The following morphological criteria were used to determine the boundary of the striatum: the superior boundary was defined by the corpus callosum, the lateral boundary by the external capsule, the medial boundary by the lateral ventricle and the corpus callosum, and the ventral boundary by the anterior commissure. The nucleus accumbens was excluded from calculations. Measurements were performed on every sixth stained coronal section throughout the brain. Both hemispheres of a given brain were analyzed separately. The number of striatal neurons was estimated using a fractionator sampling method. For each stereological probe striatal neurons were counted within a counting frame of 25 $\mu \mathrm{m} \times 25 \mu \mathrm{m}$ (a sampling site) and 10-15 sampling sites were randomly picked by the software within the outlined area. The counts were then extrapolated to estimate the total number of neurons in the striatum. For 

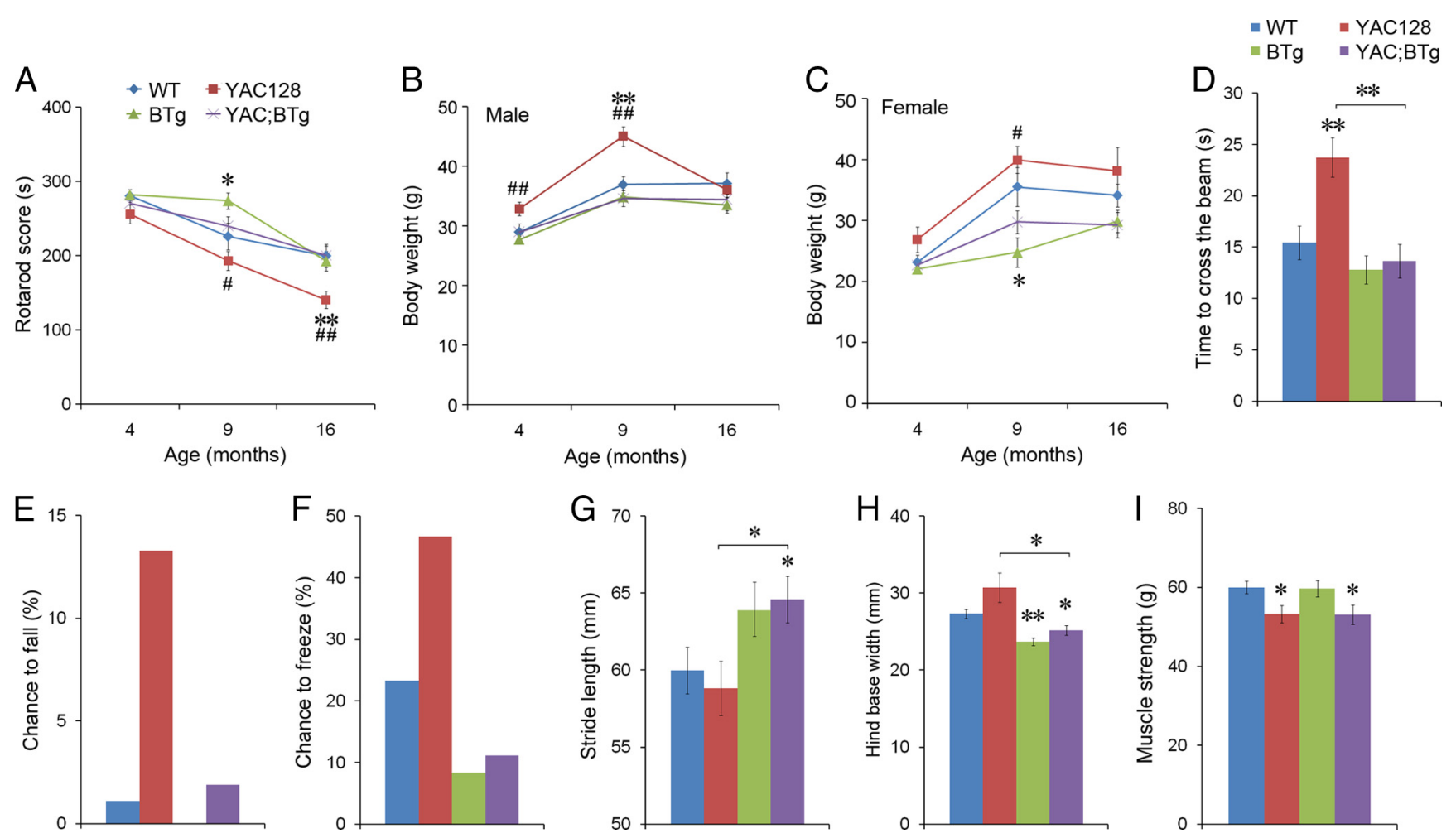

Figure 3. BDNF overexpression ameliorates motor dysfunction in YAC128 mice. A, Performance on rotarod tests. Tests were performed at 4,9 and 16 months of ages $(n=10-38$ mice per genotype at each time point). There was a significant effect of genotype $\left(F_{(3,225)}=7.208, p<0.001\right)$ and age $\left(F_{(2,225)}=36.29, p<0.0001\right)$, but no interaction between genotype and age. $\boldsymbol{B}$, Body weights of male mice $\left(n=5-19\right.$ mice per group at each time point). There was no significant effect of genotype $\left(F_{(3,118)}=0.328, p=0.805\right)$ and age $\left(F_{(2,118)}=1.080, p=0.343\right)$. $C$, Body weights of female mice $\left(n=4-19\right.$ mice per group at each time point). There was a significant effect of genotype $\left(F_{(3,98)}=7.795, p<0.001\right)$ and age $\left(F_{(2,98)}=14.76, p<0.0001\right)$, but no interaction between genotype and age. $\boldsymbol{D}$, Time to cross beam. Beam walk tests were performed at 16 months of age. YAC128 mice took longer time to cross the beam than the other 3 genotypes of mice $\left(F_{(3,85)}=8.005, p<0.0001 ; n \geq 19\right.$ mice per genotype). $\boldsymbol{E}$, Percentage of mice that fell off the beam. $\boldsymbol{F}$, Percentage of mice that stopped walking on the beam. $\boldsymbol{G}, \boldsymbol{H}$, Stride length and hind base width were measured when mice were at 13 months of age (stride length: $F_{(3,50)}=2.744, p=0.0528$; hind base width: $F_{(3,50)}=9.936, p<0.0001 ; n=11-17$ mice per genotype). $I$, Muscle strength was measured when mice were at 14 months of age. There was a significant effect of genotype on muscle strength $\left(F_{(3,49)}=3.226, p=0.0304\right)$. Error bars indicate SEs. Multiple comparisons with WT mice using $t$ test: ${ }^{*} p<0.05 ;{ }^{* *} p<0.01$. Comparisons between YAC128 mice and YAC;BTg mice using $t$ test: ${ }^{p} p<0.05$; ${ }^{\# \#} p<0.01$.

all probe runs the coefficient of error (CE Scheaffer) was $<1$. Cortical volume was estimated in the sections where the striatum volume was measured.

Analysis of dendritic structure and soma size. Golgi impregnation was performed using the Rapid GolgiStain Kit (FD NeuroTechnologies) as described previously (An et al., 2008). We used Neurolucida software (MicroBrightField Inc) to trace dendrites of Golgi-impregnated neurons under a Nikon Eclipse E800 microscope equipped with a motorized stage. Striatal MSNs were examined blind to genotype. All of analyzed MSNs were from the dorsolateral part of the striatum, well stained and isolated, and had intact dendritic arbors. Node numbers, intersections, dendritic length, and ending numbers of each traced neuron were calculated using NeuroExplorer software (MicroBrightField Inc). Six neurons were traced per animal, and the average of each measurement from these neurons was used as the value of each mouse during analysis. In Golgistained brain sections, soma size was measured using Neurolucida from at least $30 \mathrm{MSN}$ in each brain, and their mean was used as the value for the brain.

To measure spine density, we selected one major dendrite (at least $100 \mu \mathrm{m}$ long) from each neuron and marked the position of each dendritic spine along this dendrite using Neurolucida software. Spine density was calculated as a function of distance from the soma, 40 dendrites (10 dendrites per mouse) were traced for each genotype. Spine length was defined as the distance from the tip of the spine head to the interface with the dendritic stalk. High-magnification images of Golgi-stained distal dendrites ( $>100 \mu \mathrm{m}$ away from the soma) were taken, and spine length was measured on these images using NIH Image J software.

Statistical analysis. All data are expressed as mean \pm SEM. All biochemical, histological, and behavioral measurements were analyzed by either one-way ANOVA or two-way ANOVA using GraphPad Prism software. Post hoc comparisons between two genotypes at individual points were assessed with the Student's $t$ test. Comparisons of categorical data were performed with $\chi^{2}$ tests.

\section{Results}

\section{BDNF overexpression in the forebrain increases striatal BDNF in YAC128 mice}

We used a transgene (BTg) to overexpress BDNF in the forebrain. The transgene is under the control of the promoter for $\alpha$ subunit of $\mathrm{Ca}^{2+} /$ calmodulin-dependent protein kinase II (CaMKII $\alpha$ ), and it starts to express BDNF in the cerebral cortex in the first postnatal week and reaches plateau in the third postnatal week, as does the endogenous $B d n f$ gene (Huang et al., 1999). It has been reported that maturation of GABAergic innervation is accelerated in the cerebral cortex of BTg mice (Huang et al., 1999).

BTg mice were crossed to YAC128 mice to generate WT, YAC128, BTg, and YAC128;BTg double transgenic (YAC;BTg) mice. In situ hybridization on brain sections of 16-month-old mice showed similar $B d n f$ mRNA levels in the cerebral cortex of YAC128 and WT mice, indicating that transcription of the $B d n f$ gene was not altered by mutant huntingtin in YAC128 mice at this age (Fig. $1 A, C$ ). The $B d n f$ transgene under the control of the CaMKII $\alpha$ promoter resulted in an approximately threefold increase in Bdnf mRNA levels in the cerebral cortex of both BTg and YAC;BTg mice. The Bdnf transgene was also expressed in the 
striatum where the activity of the endogenous $B d n f$ gene was very low (Fig. 1A,C).

To determine whether the transgene can increase BDNF protein levels, protein extracts were prepared from striatal and cortical tissues dissected from the four genotypes of mice at 16 months of age and analyzed using Western blots (Fig. $1 B$ ). Levels of mature BDNF in YAC128 mice were similar in the cerebral cortex but significantly reduced in the striatum when compared with WT mice (Fig. 1D). Importantly, levels of mature BDNF in BTg and YAC;BTg mice were increased by $\sim 2$-fold in the cerebral cortex and by $2-3$-fold in the striatum when compared with those in WT and YAC128 mice (Fig. $1 D$ ), showing that the $B d n f$ transgene can greatly increase striatal BDNF in HD mice.

\section{Activation of the TrkB receptor in YAC128 and BTg mice}

In cultured neurons BDNF activates several signaling pathways through the TrkB receptor for a duration of up to hours, including the extracellular-signal-regulated kinase (Erk) pathway, the phosphoinositide 3-kinase (PI3K) $\rightarrow$ Akt pathway, and phospholipase C- $\gamma 1$ (PLC- $\gamma 1)$ pathway, which may mediate the effect of BDNF on neuronal differentiation, neuronal survival and soma size, and synaptic plasticity, respectively (Reichardt, 2006). We used Western blots to determine whether long-term alterations in BDNF levels change expression levels of TrkB and its downstream effectors and their activation in the cerebral cortex and striatum of the four genotypes of mice at 16 months of age. In the cerebral cortex, the expression of mutant huntingtin and/or BDNF did not alter the amounts of the full-length TrkB receptor (TrkB-F), the truncated TrkB receptor (TrkB-T), and phosphorylated-TrkB (p-TrkB) (Fig. 2A,D). Levels of PLC- $\gamma 1$, phosphorylated-PLC- $\gamma 1$ (p-PLC- $\gamma 1$, the activated form), Akt, phosphorylated Akt (p-Akt, the activated form), Erk1/2, and phosphorylated Erk1/2 (p-Erk1/2, the activated form) were normal in the cerebral cortex of YAC128, BTg, and YAC;BTg mice (Fig. 2B-E). Concordantly, levels of TrkB, p-TrkB, PLC- $\gamma 1$, p-PLC- $\gamma 1$, Erk1/2, and p-Erk1/2 in the striatum were comparable among the four genotypes of mice (Fig. 2). However, BDNF overexpression significantly increased striatal levels of Akt in BTg mice and striatal levels of both Akt and p-Akt in YAC;BTg mice (Fig. 2C,E), indicating that BDNF overexpression increased steady levels of activated Akt in the striatum of YAC128 mice. ${ }^{* *} p<0.01 ;{ }^{* *} p<0.001$.
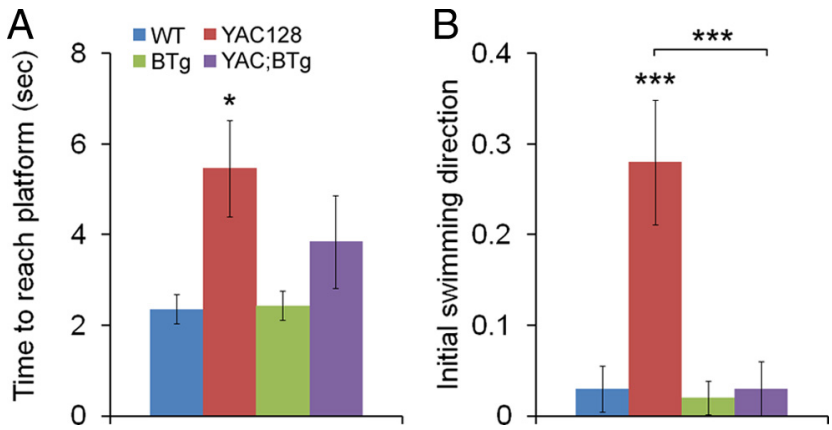

Figure 4. BDNF overexpression corrects deficits of YAC128 mice in a simple swimming test Animals were 12 months old and included 13 WT mice, 18 BTg mice, 12 YAC128 mice, and 11 YAC;BTg mice. $A$, Average latency for mice to reach the platform in three trials on day 3 . YAC128 mice took longer time to reach the platform than WT mice $\left(F_{(3,53)}=4.49, p<0.01\right)$. $\boldsymbol{B}_{\text {, }}$ Quantification of the path taken to the platform. Mice swimming initially toward the platform were given a score of 0 , whereas mice swimming initially away from the platform were given a score of 1. YAC128 mice made significant more errors in initiating the task than the other three genotypes of mice $\left(F_{(3,53)}=10.71, p<0.0001\right)$. Error bars indicate SEs. Multiple comparisons using $t$ test: ${ }^{*} p<0.05 ;{ }^{* * *} p<0.001$.
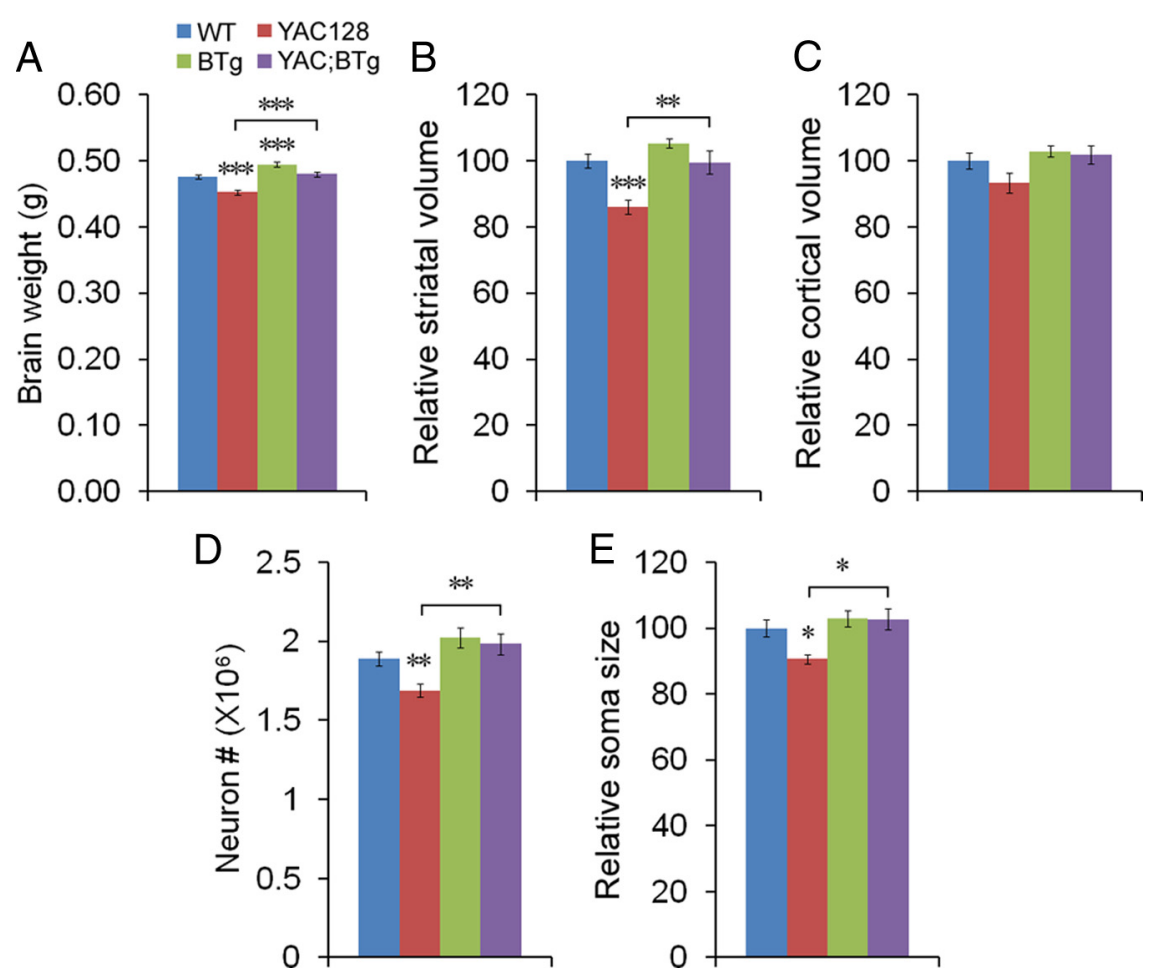

Figure 5. BDNF overexpression prevents striatal atrophy in $\mathrm{YAC} 128$ mice at 16 months of age. $A$, Brain weight $\left(F_{(3,85)}=23.62\right.$, $p<0.0001 ; n \geq 19$ mice/genotype). $\boldsymbol{B}$, Striatum volume $\left(F_{(3,21)}=12.61, p<0.0001 ; n=5-8\right.$ brains/genotype). $\boldsymbol{C}$, Cortical volume $\left(F_{(3,23)}=2.38, p=0.0958 ; n=5-10\right.$ brains/genotype). $\boldsymbol{D}$, Counts of striatal neurons. Striatal neurons were revealed by NeuN immunohistochemistry $\left(F_{(3,20)}=8.07, p=0.0010 ; n=5-7\right.$ mice/genotype). $\boldsymbol{E}$, Soma size of striatal neurons $\left(F_{(3,12)}=5.144, p<0.05 ; n=4\right.$ mice/genotype). Error bars indicate SEs. Multiple comparisons using $t$ test: ${ }^{*} p<0.05$;

\section{BDNF overexpression prevents motor dysfunction in YAC128 mice}

YAC128 mice exhibit late-onset deficits in motor coordination, as revealed by the rotarod test (Slow et al., 2003). We performed the rotarod test to monitor motor coordination of the four genotypes of mice at 4, 9, and 16 months of age (Fig. 3A). Genotype and age had a significant impact on the performance of the task (genotype: $F_{(3,225)}=7.208, p<0.001$; age: $F_{(2,225)}=36.29, p<$ $0.0001)$. YAC128 mice performed poorly on the test at 16 months of age compared with age-matched WT littermates. Furthermore, they displayed a trend toward lower performance on the task compared with WT mice at earlier time points. Impressively, YAC;BTg mice performed as well as WT mice on this task at all three time points (Fig. 3A). The difference in performance cannot be attributed to body weight differences since all four genotypes of mice had comparable body weights at 16 months of age (Fig. $3 B, C$ ).

We performed beam walk tests to further examine the beneficial effect of BDNF overexpression on motor coordination of 

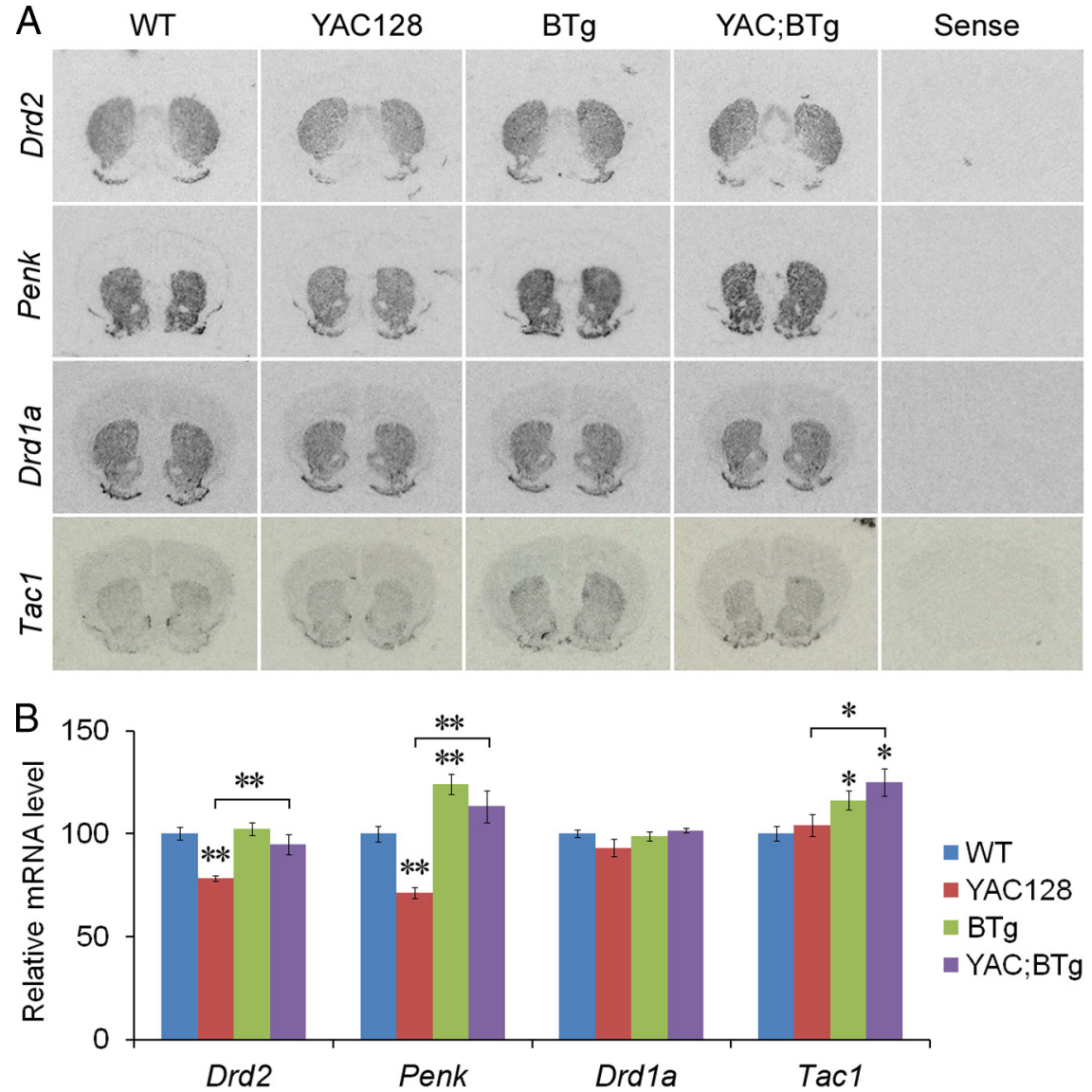

C WT YAC128 BTg YAC;BTg
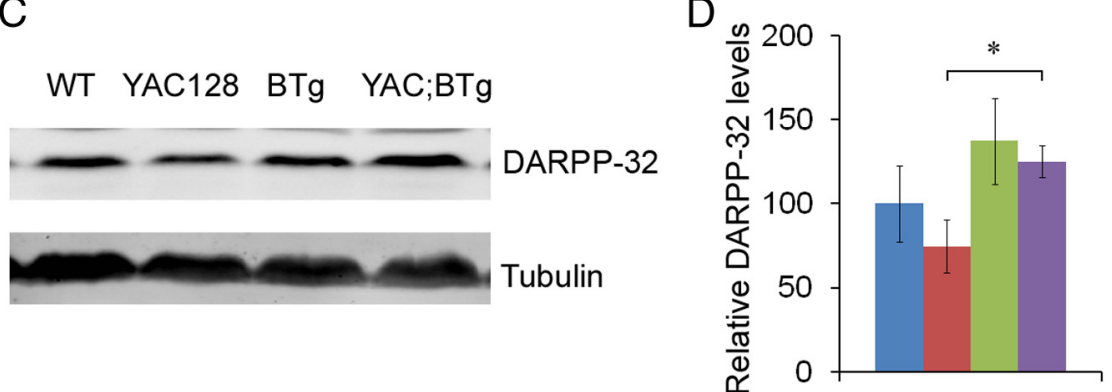

Figure 6. Effects of BDNF overexpression on gene expression of striatal neurons in YAC128 mice. $A$, Representative in situ hybridization images showing striatal levels of mRNAs for dopamine receptor D2 (Drd2), enkephalin (Penk), dopamine receptor D1a (Drd1a), and substance P (Tac1) in four genotypes of mice. $\boldsymbol{B}$, Relative levels of Drd2, Penk, Drd1a, and Tac1 mRNAs in the striatum ( $n=4$ mice per genotype). Significant differences in abundance among the four genotypes were found for $\operatorname{Drd} 2 \mathrm{mRNA}$ $\left(F_{(3,12)}=16.01, p<0.001\right)$, Penk mRNA $\left(F_{(3,12)}=13.16, p<0.001\right)$, and Tac1 mRNA $\left(F_{(3,12)}=4.328, p<0.05\right)$ but not for $\operatorname{Drd1a}$ mRNA $\left(F_{(3,12)}=1.479, p=0.270\right)$. C, Representative Western blot of striatal DARPP-32. D, Relative levels of DARPP-32 in the striatum were not significantly different among four genotypes of mice $\left(F_{(3,14)}=1.600, p=0.234 ; n=6\right.$ WT mice and 4 mice for each of the other 3 genotypes). Error bars represent SEs. Multiple comparisons using $t$ test: ${ }^{*} p<0.05 ;{ }^{* *} p<0.01$.

stride length and base width to WT mice; however, BDNF overexpression increased stride length and narrowed hind base width in BTg mice and YAC;BTg mice (Fig. 3G,H). As YAC128 mice in our colony did not display clasping, we did not examine the effect of BDNF on this phenotype that has been detected in several HD mouse models.

As shown above, BDNF overexpression improved the performance of $\mathrm{YAC} ; \mathrm{BTg}$ mice in several motor-related tasks. To determine whether the improvement results from an increase in muscle strength, we measure the grip strength of front paws in the four genotypes of mice at 14 months of age. YAC128 mice exhibited significantly weaker grip strength compared with WT mice, which was not ameliorated by BDNF overexpression (Fig. 3I). This result suggests that BDNF overexpression improves motor functions by enhancing motor coordination.

Together, the results from the behavioral tests demonstrate that BDNF overexpression in the forebrain prevents the development of motor dysfunction in YAC128 mice.

\section{BDNF overexpression mostly reverses cognitive deficits of YAC128 mice in a simple swimming test}

In addition to motor dysfunction, $\mathrm{HD}$ patients show cognitive deficits, one of which is related to procedural learning (Heindel et al., 1989; Knopman and Nissen, 1991; Gabrieli et al., 1997; Schmidtke et al., 2002). Raamsdonk and colleagues developed a simple swimming test to uncover deficits in procedural learning in YAC128 mice (Van Raamsdonk et al., 2005). In this test, mice are placed in the middle of a linear swimming chamber facing away from the escape platform located at one end, and they have to learn to turn around and swim to the platform. We used this test to examine procedural learning of the four genotypes of mice at 12 months of age. After $2 \mathrm{~d}$ of training, the vast majority of mice learned to turn immediately to reach the platform (Fig. 4A).

YAC128 mice. YAC128 mice at 16 months of age took a significantly longer time to cross the beam, compared with WT mice (Fig. 3D). YAC128 mice also exhibited a higher tendency to fall from the beam (Fig. $3 E$ ) and to freeze on the beam (Fig. $3 F$ ). $\mathrm{BDNF}$ overexpression in the forebrain normalized all these abnormalities, as YAC;BTg mice showed no difference from WT mice on this test (Fig. 3D-F).

To further determine the effect of BDNF overexpression on motor coordination, we assessed gait abnormalities in the four genotypes of mice by footprint pattern analysis. The footprint pattern was quantitatively evaluated by measurements of stride length and base width for hindpaws. YAC128 mice at 13 months of age had similar
WT and BTg mice took a similar amount of time to reach platform (WT, $2.36 \pm 0.33 \mathrm{~s}$; BTg, $2.44 \pm 0.32 \mathrm{~s} ; p=0.86$ ), while YAC128 mice took twice as much time to reach platform compared with WT mice (YAC128, $5.47 \pm 1.06 \mathrm{~s} ; p<0.01$ ). YAC;BTg mice took longer time than WT mice to reach platform (YAC; BTg, $3.85 \pm 1.03 \mathrm{~s})$, but the difference was not significant $(p=$ $0.15)$. The time increase mainly resulted from floating behavior of one YAC;BTg mouse in one trial. If this trial is excluded, the time for YAC;BTg mice to reach platform $(2.95 \pm 0.40 \mathrm{~s})$ is not significantly different from those for WT mice $(p=0.26)$ and BTg mice $(p=0.33)$, but significantly shorter than that for YAC128 mice $(p=0.044)$. 
To determine whether the reduced latency for YAC;BTg mice to reach the platform relative to WT mice arose from improved procedural learning, we examined the path for each mouse to reach the platform. In contrast to YAC128 mice, which frequently swam initially at the wrong direction, YAC;BTg mice swam directly to the platform in nearly all trials, as did WT and BTg mice (errors in initial swimming direction: WT, 1 of 39 trials; BTg, 1 of 54 trials; YAC128, 10 of 36 trials; YAC;BTg, 1 of 33 trials; $\chi^{2}=24.51, p<$ $0.0001)$. To quantify this phenotype, we arbitrarily assign mice swimming toward the platform a score of 0 and mice swimming away from the platform a score of 1 . According to this analysis, YAC128 mice showed a significant deficit in initiating the task in the correct direction and the deficit was corrected in YAC;BTg mice (Fig. 4B). This result shows that BDNF overexpression reverses the deficit in procedural learning in YAC128 mice.

\section{BDNF overexpression prevented brain atrophy and loss of striatal neurons in YAC128 mice}

YAC128 mice exhibit brain atrophy, as do many other HD mouse models. They also show age-dependent loss of striatal neurons (Slow et al., 2003). At 16 months of age, brain weight decreased by $5 \%$ in YAC128 mice compared with WT mice

(Fig. 5A). Striatal atrophy is likely an important contributor to the brain weight loss, as the striatum of YAC128 mice was reduced by $14 \%$ in volume (Fig. $5 B$ ). Cortical volume in YAC128 mice was also reduced, but did not reach significance $(p=0.113$; Fig. 5C). To identify the cause for striatal atrophy, we used NeuN immunohistochemistry to reveal neurons, counted striatal neurons on NeuN-stained brain sections using a stereological method, and measured the soma size of striatal neurons on Golgi-stained sections. The number of striatal neurons and their soma size were reduced by $11 \%$ (Fig. $5 D$ ) and $9 \%$ (Fig. $5 E$ ), respectively. On the contrary, BTg mice had significantly higher brain weight than WT mice (Fig. $5 A$ ), but their striatal volume, cortical volume, and number and soma size of striatal neurons were not significantly different from WT mice (Fig. 5B-E). BDNF overexpression in YAC128 mice reversed loss of brain weight, striatal atrophy, loss of striatal neurons, and somatic atrophy of striatal neurons (Fig. 5). These results indicate a protective effect of BDNF against brain atrophy and neuronal loss in the striatum of YAC128 mice.

\section{Effect of BDNF overexpression on levels of dopamine receptor D2, enkephalin, and DARPP-32}

Immunohistochemical studies of postmortem tissues show that striatal MSNs coexpressing dopamine receptor D2 (DRD2) and enkephalin (Enk) are more vulnerable than those coexpressing dopamine receptor D1a (DRD1a) and substance P (SP) in HD patients. Although previous studies indicate reduced levels of mRNA for Enk precursor, preproenkephalin (Penk), but normal expression of dopamine receptors in YAC128 mice (Benn
B

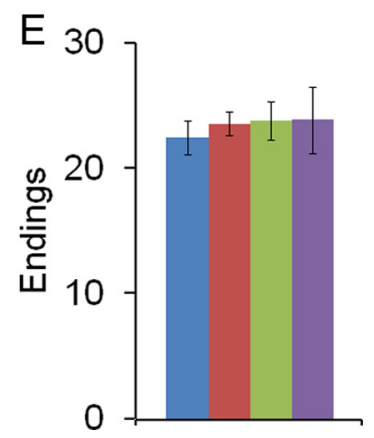

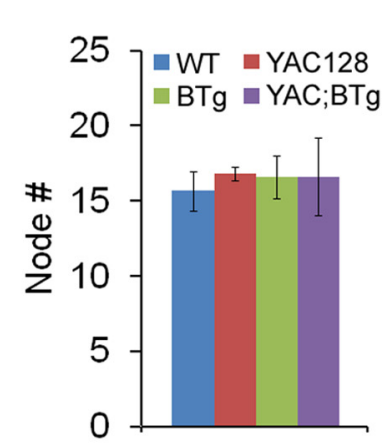

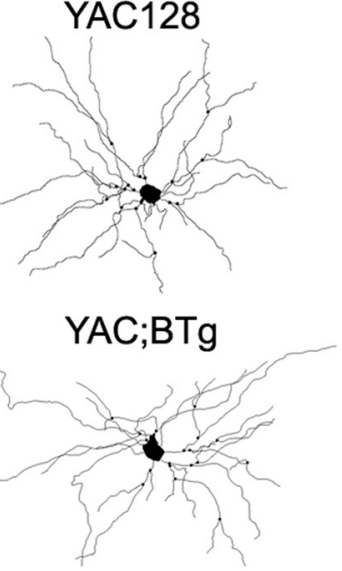

Figure 7. BDNF overexpression does not affect dendritic arborization of striatal MSNs. $\boldsymbol{A}$, Representative dendritic arbors of

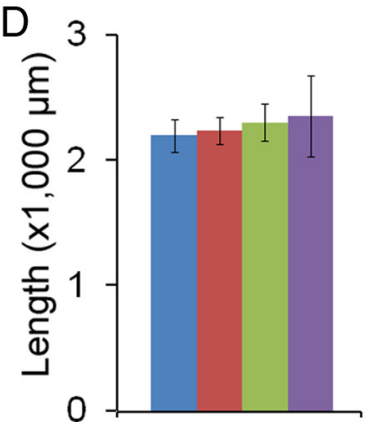

(1)

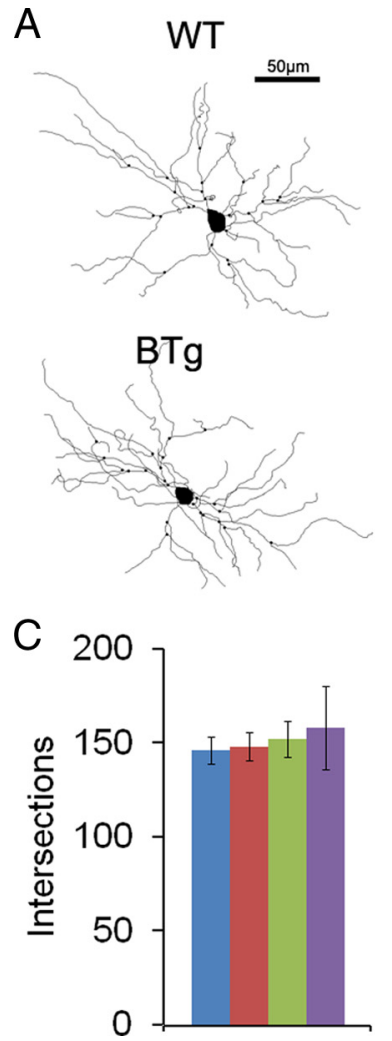
$\boldsymbol{B}-\boldsymbol{E}$, Quantification of node number, intersection, total dendrite length, and dendritic endings in e, 40 MSNs from 4 mice were traced. No significant differences were detected between the four genotypes (node number: $F_{(3,12)}=0.104, p=0.956$; intersections: $F_{(3,12)}=0.159, p=0.922$; dendritic length: $F_{(3,12)}=0.121$, $p=0.946$; dendritic endings: $\left.F_{(3,12)}=0.144, p=0.932\right)$.

et al., 2007), we found that levels of both Drd2 and Penk mRNAs were significantly reduced in YAC128 mice at 16 months of age (Fig. $6 A, B, p<0.01$ ). However, mRNAs levels for Drd1 $a$ and SP precursor tachykinin 1 (Tac1) were not affected in these animals (Fig. $6 A, B$ ). These results suggest that aging YAC128 mice recapitulate the selective degeneration feature of HD patients. Importantly, BDNF overexpression normalized levels of both $\operatorname{Drd} 2$ and Penk mRNA levels in YAC;BTg mice (Fig. 6A,B). Additionally, BDNF overexpression also increased striatal levels of Tac1 mRNA in BTg and YAC;BTg mice (Fig. 6A,B). DARPP-32 is a $32 \mathrm{kDa}$ dopamine- and cAMP-regulated phosphoprotein important for dopamine neurotransmission (Svenningsson et al., 2004), and its expression is severely impaired in the striatum of R6/1 mice (Gharami et al., 2008). We observed a 25\% reduction of DARPP-32 levels in the striatum of YAC128 mice at 16 months of age compared with WT mice, but the reduction did not reach significance ( $p=0.44$; Fig. $6 C, D)$. This result is similar to what was previously reported (Van Raamsdonk et al., 2006). As observed in R6/1 mice (Gharami et al., 2008), BDNF overexpression significantly increased DARPP-32 levels in YAC;BTg mice compared with YAC128 mice (Fig. 6C,D). Taken together, these results indicate that BDNF overexpression increases the expression of some genes important for the function of the striatum.

\section{BDNF overexpression normalized spine morphology of striatal medium spiny neurons}

Marked morphological changes in the dendrites of MSNs have been reported in HD patients (Graveland et al., 1985; Ferrante et al., 1991) as well as in R6/1 mice (Spires et al., 2004b). We used 

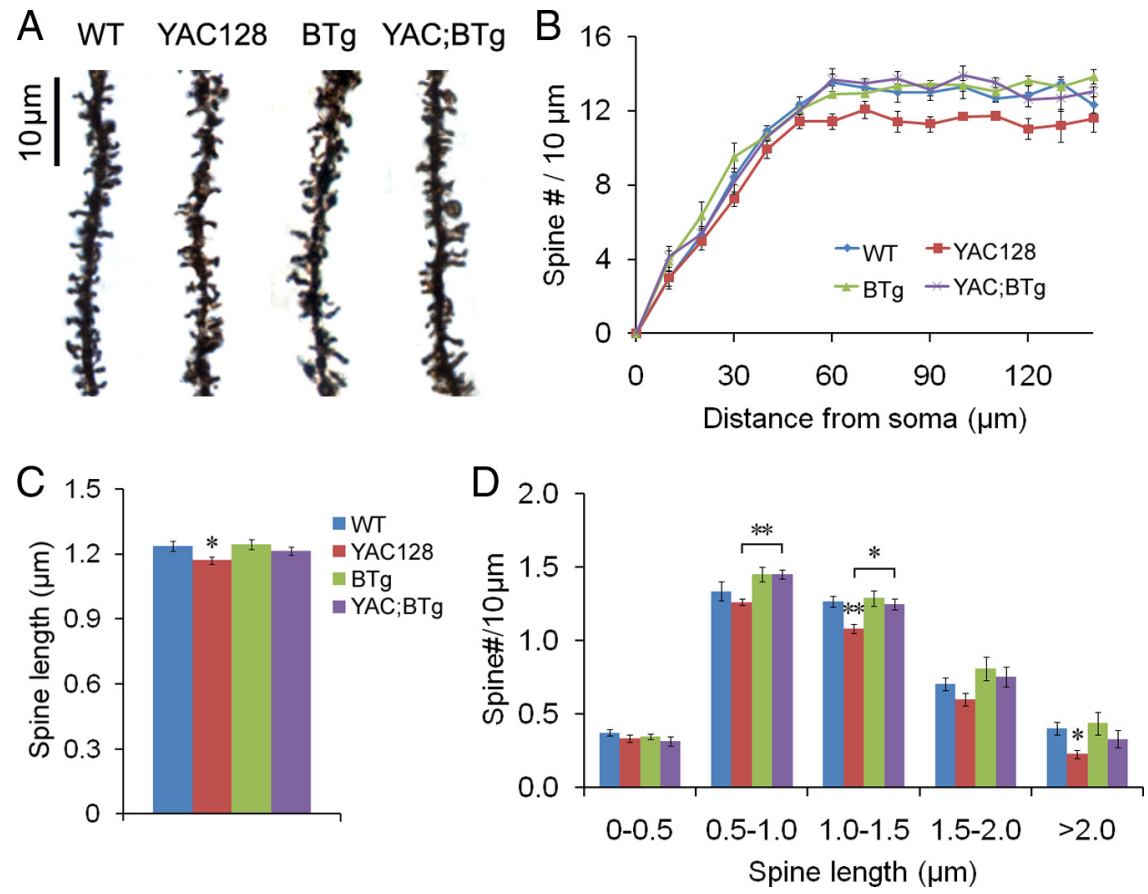

Figure 8. BDNF overexpression in the forebrain normalizes spine abnormalities of MSNs in YAC128 mice at 16 months of age. $\boldsymbol{A}$, Representative images of distal dendrites of MSNs in four genotypes of mice. $\boldsymbol{B}$, Spine density as a function of distance from the soma in a major dendrite of MSNs ( $n=4$ mice; 10 neurons were analyzed in each mouse). Two-way ANOVA analysis indicates a significant difference in spine density between genotypes $\left(F_{(3,12)}=15.42, p<0.0001\right)$. Post hoc tests show significant difference in spine density between WT and YAC128 at 60,90, 100,110, and $130 \mu \mathrm{m}$ from the soma and between YAC128 and YAC;BTg at 60-110 $\mu \mathrm{m}$ from the soma $(p<0.05)$. C, Spine length of MSNs in four genotypes of mice. There was a significant effect of genotype on spine length $\left(F_{(3,156)}=2.778, p<0.05 ; n=40\right.$ neurons from 4 mice per genotype). $\boldsymbol{D}$, Distribution of spine length ( $n=4$ mice per genotype). Approximately 750 spines in each brain were quantified. Error bars represent $S E s$. Multiple comparisons using $t$ test: ${ }^{*} p<0.05 ;{ }^{* *} p<0.01$.

Golgi staining to examine whether dendritic morphology of MSNs is altered in YAC128 mice and, if so, whether BDNF overexpression can normalize the abnormality. We traced the dendrites of Golgi-stained MSNs in the four genotypes of mice at 16 months of age (Fig. 7A). Node number, intersection number, total dendrite length, and endings per neuron from reconstructed dendritic arbors were calculated. These quantitative morphometric analyses revealed that MSNs in all four genotypes of mice had comparable dendritic arbors (Fig. $7 B-E$ ).

Each MSN has thousands of dendritic spines, which are the postsynaptic sites for a vast majority of excitatory inputs. We examined whether the expression of mutant huntingtin alters dendritic spines of MSNs on Golgi-stained brain sections (Fig. $8 A$ ). MSNs in YAC128 mice had significantly lower spine densities, especially on distal dendrites (Fig. $8 B$ ), and shorter dendritic spines (Fig. 8C) when compared with WT mice. The latter abnormality mainly resulted from lower numbers of long dendritic spines (Fig. 8D). Although density and length of spines were normal in BTg mice, BDNF overexpression did rescue the abnormal spine phenotype in YAC128 mice (Fig. $8 B-D$ ).

\section{Discussion}

In adults striatal BDNF arrives by anterograde transport from cell bodies located primarily in the cerebral cortex, secondarily in the substantia nigra, and tertiarily in the thalamus (Altar et al., 1997; Altar and DiStefano, 1998). Levels of mature BDNF in the striatum are significantly reduced in HD patients (Ferrer et al., 2000; Gauthier et al., 2004) and mouse models (Ferrer et al., 2000; Spires et al., 2004a). Several studies suggest that this reduction results from inhibition of $B d n f$ gene expression (Zuccato et al., 2001, 2003) and/or deficits in BDNF anterograde transport (Gauthier et al., 2004; Her and Goldstein, 2008), caused by mutant huntingtin. We found that levels of BDNF protein were reduced by $\sim 40 \%$ in the striatum of YAC128 mice at 16 months of age. However, we did not find a reduction in $B d n f$ mRNA levels in the cerebral cortex of YAC128 mice, suggesting that $B d n f$ gene transcription is normal in the cortex of these animals. As blockage of anterograde transport should increase BDNF levels at the source, normal levels of mature BDNF in the cortex of aging YAC128 mice suggest that deficits in BDNF transport from the cortex to the striatum are unlikely the cause for the reduction in striatal levels of mature BDNF. Furthermore, there is little $B d n f$ gene expression in the striatum of WT mice, so downregulation of $B d n f$ gene expression in the striatum of YAC128 mice cannot be the cause for the reduction either. However, our data does not allow us to address the possibility of reduced BDNF inputs to the striatum from the substantia nigra and the thalamus.

One potential cause for reduced neurotrophic support of striatal neurons in HD may be deficits in processing of proBDNF. Immunoblotting analysis revealed a reduction in striatal levels of mature BDNF in R6/1 mice (Spires et al., 2004a; Gharami et al., 2008) and HD patients (Ferrer et al., 2000; Gauthier et al., 2004). In this study, we found that striatal levels of mature BDNF were also reduced in YAC128 mice. However, ELISA assays show normal striatal levels of BDNF in R6/1 mice (Canals et al., 2004; Pang et al., 2006) and increased striatal levels of BDNF in YAC72 mice (Seo et al., 2008). As ELISA assays detect both mature BDNF and pro-BDNF, this discrepancy suggests that processing of pro-BDNF may be impaired in the striatum, leading to accumulation of pro-BDNF in the striatum. Since current BDNF antibodies are still problematic in detecting pro-BDNF on immunoblots, future development of specific BDNF antibodies or utilization of tagged $B d n f$ knockin mice (Matsumoto et al., 2008; Yang et al., 2009) will help uncover the effect of mutant huntingtin on BDNF maturation.

We previously demonstrated that BDNF overexpression in the forebrain significantly improved the performance of R6/1 mice on the rotarod test (Gharami et al., 2008). In this study we found that BDNF overexpression in the forebrain virtually prevented motor dysfunction in aging YAC128 mice, as revealed by rotarod and beam walk tests. R6/1 mice display faster progressed diseases and more severe motor deficits than YAC128 mice (Davies et al., 1997; Slow et al., 2003). It is unclear whether the apparent better rescue in YAC128 mice in terms of motor coordination is due to more effective actions of BDNF in slowly progressed HD mice or as a result of the motor dysfunction of R6/1 mice that is too severe to be reversed. In addition to motor function, BDNF overexpression also prevented brain weight loss and increased levels of some proteins or peptides important for striatal function, such as DARPP-32 and enkephalin, in both R6/1 
and YAC128 mice. However, activation of TrkB and Akt behaves differently in response to increased BDNF levels in these two HD models. Levels of p-TrkB and p-Akt were reduced in the R6/1 striatum but not in the YAC128 striatum, which should be attributable to a more severe phenotype and a much deeper reduction of striatal BDNF levels in R6/1 mice than in YAC128 mice. The normal p-TrkB level may explain why BDNF overexpression did not increase the steady levels of $p$-TrkB and its activated downstream effectors in the cortex and striatum of YAC128 mice with exception of striatal Akt. YAC128 mice exhibit agedependent loss of striatal neurons and deficits in procedural learning (Slow et al., 2003; Van Raamsdonk et al., 2005). These unique phenotypes allowed us to address whether BDNF overexpression could rescue striatal degeneration and cognitive deficits associated with HD. Our results indicate that BDNF overexpression in the forebrain completely rescues striatal neuron loss and corrects the deficit in procedural learning in YAC128 mice.

We did not detect significant motor deficits on the rotarod test in YAC128 mice until 16 months of age, which is different from previous studies that found motor dysfunction in younger mice (Slow et al., 2003; Van Raamsdonk et al., 2005). This discrepancy likely results from differences in genetic background. The mice used in this study were on the C57BL/6J background, which have a later onset of motor deficiency (Van Raamsdonk et al., 2007). The later onset may also explain why we did not detect gait abnormalities that were reported in FVB/N YAC128 mice (Wang et al., 2010). It was reported that levels of p-Akt were increased in the striatum of $H d h^{Q 111 / Q 111}$ knockin and R6/1 mice (Gines et al., 2003; Saavedra et al., 2010). However, we observed a reduction or no change in striatal p-Akt levels in R6/1 mice (Gharami et al., 2008) and YAC128 mice. Since steady levels of p-Akt are determined by equilibrium of extracellular stimulations and activities of phosphatases, they could be greatly influenced by differences in strain and genetic background. It is worthy to note that one study found lower levels of p-Akt in the striatum of HD rats and patients (Colin et al., 2005).

We found that the striatum lost a significant number of neurons and that the remaining striatal neurons had smaller somata but normal dendritic arbors in YAC128 mice. These observations indicate that striatal atrophy in these $\mathrm{HD}$ mice mainly results from neuronal loss and neuronal atrophy. BDNF overexpression in the forebrain completely reversed striatal atrophy in YAC128 mice. As the number and dendritic arbors of striatal neurons are not significantly different between WT and BTg mice, this marked effect likely rises from protection of striatal neurons from atrophy and death rather than increased neurogenesis and enlarged dendritic arbors, which may be related to increased steady levels of activated Akt in YAC;BTg mice. Interestingly, BTg mice have significantly larger brains than WT mice, which may result from a combination of subtle effects. For instance, in BTg mice the striatum has 7\% more neurons and their cell bodies are 3\% larger compared with WT mice. The combination of these subtle and insignificant differences leads to a significantly larger brain in BTg mice.

Despite a previous study indicates that receptor abnormalities in YAC128 mice appear limited to glutamate receptors (Benn et al., 2007), we did find reduced levels of Drd2 mRNA in these mice. Since MSNs of the indirect pathway are most affected in HD patients (Reiner et al., 1988), the observed reduction in the expression of Drd2 and Penk may be a reflection of selective degeneration of MSNs in the indirect pathway in YAC128 mice. In addition to altered expression of neurotransmitter receptors, ab- normal dendritic spines certainly contribute to motor dysfunction in YAC128 mice. We found that dendritic spine density and dendritic spine length were reduced in MSNs of YAC128 mice. A similar phenotype was previously observed in R6/1 mice (Spires et al., 2004b). Our data further suggest that this spine abnormality is due to loss of long spines. Since dendritic spines continue to form and disappear in the mature brain (Trachtenberg et al., 2002) and dendritic spines change morphology from long and thin to short and stubby when they become mature (Bagni and Greenough, 2005), this spine phenotype suggests that mutant huntingtin inhibits the formation of new spines in the striatum. Consistent with the established role of BDNF in spine formation (Baquet et al., 2004; Ji et al., 2005), spine abnormality was normalized in YAC;BTg mice.

In summary, this study suggests that increasing striatal BDNF supply by overexpression may have therapeutic potential for HD. However, we noticed that some BTg mice and YAC;BTg mice developed seizure by 16 months of age. Several studies have found a link between BDNF and epileptogenesis. For instance, epileptogenesis is reduced in mice carrying one copy of the $B d n f$ gene (Kokaia et al., 1995; Barton and Shannon, 2005) or in mice overexpressing a dominant-negative TrkB receptor (Lähteinen et al., 2002). Mice overexpressing BDNF throughout the brain show increased seizure susceptibility to kainic acid in vivo and hyperexcitability in CA3 region of the hippocampus and entorhinal cortex in vitro (Croll et al., 1999). The Bdnftransgene used in this study is also expressed in epileptogenic regions such as the entorhinal cortex and hippocampus, which could be the cause for increased seizure in BTg and YAC;BTg mice. Therefore, it will be necessary to avoid expressing BDNF in these brain regions if $\mathrm{BDNF}$ is used to treat $\mathrm{HD}$ patients.

\section{References}

Altar CA, DiStefano PS (1998) Neurotrophin trafficking by anterograde transport. Trends Neurosci 21:433-437.

Altar CA, Cai N, Bliven T, Juhasz M, Conner JM, Acheson AL, Lindsay RM, Wiegand SJ (1997) Anterograde transport of brain-derived neurotrophic factor and its role in the brain. Nature 389:856-860.

An JJ, Gharami K, Liao GY, Woo NH, Lau AG, Vanevski F, Torre ER, Jones KR, Feng Y, Lu B, Xu B (2008) Distinct role of long 3' UTR BDNF mRNA in spine morphology and synaptic plasticity in hippocampal neurons. Cell 134:175-187.

Bagni C, Greenough WT (2005) From mRNP trafficking to spine dysmorphogenesis: the roots of fragile X syndrome. Nat Rev Neurosci 6:376-387.

Baquet ZC, Gorski JA, Jones KR (2004) Early striatal dendrite deficits followed by neuron loss with advanced age in the absence of anterograde cortical brain-derived neurotrophic factor. J Neurosci 24:4250-4258.

Barton ME, Shannon HE (2005) The seizure-related phenotype of brainderived neurotrophic factor knockdown mice. Neuroscience 136:563-569.

Benn CL, Slow EJ, Farrell LA, Graham R, Deng Y, Hayden MR, Cha JH (2007) Glutamate receptor abnormalities in the YAC128 transgenic mouse model of Huntington's disease. Neuroscience 147:354-372.

Canals JM, Pineda JR, Torres-Peraza JF, Bosch M, Martín-Ibañez R, Muñoz MT, Mengod G, Ernfors P, Alberch J (2004) Brain-derived neurotrophic factor regulates the onset and severity of motor dysfunction associated with enkephalinergic neuronal degeneration in Huntington's disease. J Neurosci 24:7727-7739.

Cho SR, Benraiss A, Chmielnicki E, Samdani A, Economides A, Goldman SA (2007) Induction of neostriatal neurogenesis slows disease progression in a transgenic murine model of Huntington disease. J Clin Invest 117:2889-2902.

Colin E, Régulier E, Perrin V, Dürr A, Brice A, Aebischer P, Déglon N, Humbert S, Saudou F (2005) Akt is altered in an animal model of Huntington's disease and in patients. Eur J Neurosci 21:1478-1488.

Croll SD, Suri C, Compton DL, Simmons MV, Yancopoulos GD, Lindsay 
RM, Wiegand SJ, Rudge JS, Scharfman HE (1999) Brain-derived neurotrophic factor transgenic mice exhibit passive avoidance deficits, increased seizure severity and in vitro hyperexcitability in the hippocampus and entorhinal cortex. Neuroscience 93:1491-1506.

Davies SW, Turmaine M, Cozens BA, DiFiglia M, Sharp AH, Ross CA, Scherzinger E, Wanker EE, Mangiarini L, Bates GP (1997) Formation of neuronal intranuclear inclusions underlies the neurological dysfunction in mice transgenic for the HD mutation. Cell 90:537-548.

Ferrante RJ, Kowall NW, Richardson EP Jr (1991) Proliferative and degenerative changes in striatal spiny neurons in Huntington's disease: a combined study using the section-Golgi method and calbindin D28k immunocytochemistry. J Neurosci 11:3877-3887.

Ferrer I, Goutan E, Marín C, Rey MJ, Ribalta T (2000) Brain-derived neurotrophic factor in Huntington disease. Brain Res 866:257-261.

Gabrieli JD, Stebbins GT, Singh J, Willingham DB, Goetz CG (1997) Intact mirror-tracing and impaired rotary-pursuit skill learning in patients with Huntington's disease: evidence for dissociable memory systems in skill learning. Neuropsychology 11:272-281.

Gauthier LR, Charrin BC, Borrell-Pagès M, Dompierre JP, Rangone H, Cordelières FP, De Mey J, MacDonald ME, Lessmann V, Humbert S, Saudou F (2004) Huntingtin controls neurotrophic support and survival of neurons by enhancing BDNF vesicular transport along microtubules. Cell 118:127-138.

Gharami K, Xie Y, An JJ, Tonegawa S, Xu B (2008) Brain-derived neurotrophic factor overexpression in the forebrain ameliorates Huntington's disease phenotypes in mice. J Neurochem 105:369-379.

Gines S, Ivanova E, Seong IS, Saura CA, MacDonald ME (2003) Enhanced Akt signaling is an early pro-survival response that reflects $N$-methyl-Daspartate receptor activation in Huntington's disease knock-in striatal cells. J Biol Chem 278:50514-50522.

Giralt A, Rodrigo T, Martin ED, Gonzalez JR, Milà M, Ceña V, Dierssen M, Canals JM, Alberch J (2009) Brain-derived neurotrophic factor modulates the severity of cognitive alterations induced by mutant huntingtin: involvement of phospholipaseCgamma activity and glutamate receptor expression. Neuroscience 158:1234-1250.

Graveland GA, Williams RS, DiFiglia M (1985) Evidence for degenerative and regenerative changes in neostriatal spiny neurons in Huntington's disease. Science 227:770-773.

Heindel WC, Salmon DP, Shults CW, Walicke PA, Butters N (1989) Neuropsychological evidence for multiple implicit memory systems: a comparison of Alzheimer's, Huntington's, and Parkinson's disease patients. J Neurosci 9:582-587.

Her LS, Goldstein LS (2008) Enhanced sensitivity of striatal neurons to axonal transport defects induced by mutant huntingtin. J Neurosci 28:13662-13672.

Huang ZJ, Kirkwood A, Pizzorusso T, Porciatti V, Morales B, Bear MF, Maffei L, Tonegawa S (1999) BDNF regulates the maturation of inhibition and the critical period of plasticity in mouse visual cortex. Cell 98:739-755.

Ivkovic S, Ehrlich ME (1999) Expression of the striatal DARPP-32/ ARPP-21 phenotype in GABAergic neurons requires neurotrophins in vivo and in vitro. J Neurosci 19:5409-5419.

Ji Y, Pang PT, Feng L, Lu B (2005) Cyclic AMP controls BDNF-induced TrkB phosphorylation and dendritic spine formation in mature hippocampal neurons. Nat Neurosci 8:164-172.

Knopman D, Nissen MJ (1991) Procedural learning is impaired in Huntington's disease: evidence from the serial reaction time task. Neuropsychologia 29:245-254.

Kokaia M, Ernfors P, Kokaia Z, Elmér E, Jaenisch R, Lindvall O (1995) Suppressed epileptogenesis in BDNF mutant mice. Exp Neurol 133:215-224.

Lähteinen S, Pitkänen A, Saarelainen T, Nissinen J, Koponen E, Castrén E (2002) Decreased BDNF signalling in transgenic mice reduces epileptogenesis. Eur J Neurosci 15:721-734.

Liu J, Tang TS, Tu H, Nelson O, Herndon E, Huynh DP, Pulst SM, Bezprozvanny I (2009) Deranged calcium signaling and neurodegeneration in spinocerebellar ataxia type 2. J Neurosci 29:9148-9162.

Mangiarini L, Sathasivam K, Seller M, Cozens B, Harper A, Hetherington C, Lawton M, Trottier Y, Lehrach H, Davies SW, Bates GP (1996) Exon 1 of the HD gene with an expanded CAG repeat is sufficient to cause a progressive neurological phenotype in transgenic mice. Cell 87:493-506.

Matsumoto T, Rauskolb S, Polack M, Klose J, Kolbeck R, Korte M, Barde YA (2008) Biosynthesis and processing of endogenous BDNF: CNS neurons store and secrete BDNF, not pro-BDNF. Nat Neurosci 11:131-133.
Mizuno K, Carnahan J, Nawa H (1994) Brain-derived neurotrophic factor promotes differentiation of striatal GABAergic neurons. Dev Biol 165:243-256.

Pang TY, Stam NC, Nithianantharajah J, Howard ML, Hannan AJ (2006) Differential effects of voluntary physical exercise on behavioral and brainderived neurotrophic factor expression deficits in Huntington's disease transgenic mice. Neuroscience 141:569-584.

Peng Q, Masuda N, Jiang M, Li Q, Zhao M, Ross CA, Duan W (2008) The antidepressant sertraline improves the phenotype, promotes neurogenesis and increases BDNF levels in the R6/2 Huntington's disease mouse model. Exp Neurol 210:154-163.

Pineda JR, Canals JM, Bosch M, Adell A, Mengod G, Artigas F, Ernfors P, Alberch J (2005) Brain-derived neurotrophic factor modulates dopaminergic deficits in a transgenic mouse model of Huntington's disease. J Neurochem 93:1057-1068.

Reichardt LF (2006) Neurotrophin-regulated signalling pathways. Philos Trans R Soc Lond B Biol Sci 361:1545-1564.

Reiner A, Albin RL, Anderson KD, D’Amato CJ, Penney JB, Young AB (1988) Differential loss of striatal projection neurons in Huntington disease. Proc Natl Acad Sci 85:5733-5737.

Saavedra A, García-Martínez JM, Xifró X, Giralt A, Torres-Peraza JF, Canals JM, Díaz-Hernández M, Lucas JJ, Alberch J, Pérez-Navarro E (2010) PH domain leucine-rich repeat protein phosphatase 1 contributes to maintain the activation of the PI3K/Akt pro-survival pathway in Huntington's disease striatum. Cell Death Differ 17:324-335.

Schmidtke K, Manner H, Kaufmann R, Schmolck H (2002) Cognitive procedural learning in patients with fronto-striatal lesions. Learn Mem 9:419-429.

Seo H, Kim W, Isacson O (2008) Compensatory changes in the ubiquitinproteasome system, brain-derived neurotrophic factor and mitochondrial complex II/III in YAC72 and R6/2 transgenic mice partially model Huntington's disease patients. Hum Mol Genet 17:3144-3153.

Simmons DA, Rex CS, Palmer L, Pandyarajan V, Fedulov V, Gall CM, Lynch G (2009) Up-regulating BDNF with an ampakine rescues synaptic plasticity and memory in Huntington's disease knockin mice. Proc Natl Acad Sci 106:4906-4911.

Slow EJ, van Raamsdonk J, Rogers D, Coleman SH, Graham RK, Deng Y, Oh R, Bissada N, Hossain SM, Yang YZ, Li XJ, Simpson EM, Gutekunst CA, Leavitt BR, Hayden MR (2003) Selective striatal neuronal loss in a YAC128 mouse model of Huntington disease. Hum Mol Genet 12:1555-1567.

Spires TL, Grote HE, Varshney NK, Cordery PM, van Dellen A, Blakemore C, Hannan AJ (2004a) Environmental enrichment rescues protein deficits in a mouse model of Huntington's disease, indicating a possible disease mechanism. J Neurosci 24:2270-2276.

Spires TL, Grote HE, Garry S, Cordery PM, Van Dellen A, Blakemore C, Hannan AJ (2004b) Dendritic spine pathology and deficits in experiencedependent dendritic plasticity in R6/1 Huntington's disease transgenic mice. Eur J Neurosci 19:2799-2807.

Strand AD, Baquet ZC, Aragaki AK, Holmans P, Yang L, Cleren C, Beal MF, Jones L, Kooperberg C, Olson JM, Jones KR (2007) Expression profiling of Huntington's disease models suggests that brain-derived neurotrophic factor depletion plays a major role in striatal degeneration. J Neurosci 27:11758-11768.

Svenningsson P, Nishi A, Fisone G, Girault JA, Nairn AC, Greengard P (2004) DARPP-32: an integrator of neurotransmission. Annu Rev Pharmacol Toxicol 44:269-296.

Trachtenberg JT, Chen BE, Knott GW, Feng G, Sanes JR, Welker E, Svoboda $\mathrm{K}$ (2002) Long-term in vivo imaging of experience-dependent synaptic plasticity in adult cortex. Nature 420:788-794.

Van Raamsdonk JM, Pearson J, Slow EJ, Hossain SM, Leavitt BR, Hayden MR (2005) Cognitive dysfunction precedes neuropathology and motor abnormalities in the YAC128 mouse model of Huntington's disease. J Neurosci 25:4169-4180.

Van Raamsdonk JM, Pearson J, Murphy Z, Hayden MR, Leavitt BR (2006) Wild-type huntingtin ameliorates striatal neuronal atrophy but does not prevent other abnormalities in the YAC128 mouse model of Huntington disease. BMC Neurosci 7:80.

Van Raamsdonk JM, Metzler M, Slow E, Pearson J, Schwab C, Carroll J, Graham RK, Leavitt BR, Hayden MR (2007) Phenotypic abnormalities in the YAC128 mouse model of Huntington disease are penetrant on 
multiple genetic backgrounds and modulated by strain. Neurobiol Dis 26:189-200.

Ventimiglia R, Mather PE, Jones BE, Lindsay RM (1995) The neurotrophins BDNF, NT-3 and NT-4/5 promote survival and morphological and biochemical differentiation of striatal neurons in vitro. Eur J Neurosci 7:213-222.

Vonsattel JP, DiFiglia M (1998) Huntington disease. J Neuropathol Exp Neurol 57:369-384.

Wang H, Chen X, Li Y, Tang TS, Bezprozvanny I (2010) Tetrabenazine is neuroprotective in Huntington's disease mice. Mol Neurodegener $5: 18$.

Xu B, Zang K, Ruff NL, Zhang YA, McConnell SK, Stryker MP, Reichardt LF (2000) Cortical degeneration in the absence of neurotrophin signaling: dendritic retraction and neuronal loss after removal of the receptor TrkB. Neuron 26:233-245.
Xu B, Goulding EH, Zang K, Cepoi D, Cone RD, Jones KR, Tecott LH, Reichardt LF (2003) Brain-derived neurotrophic factor regulates energy balance downstream of melanocortin-4 receptor. Nat Neurosci 6:736-742.

Yang J, Siao CJ, Nagappan G, Marinic T, Jing D, McGrath K, Chen ZY, Mark W, Tessarollo L, Lee FS, Lu B, Hempstead BL (2009) Neuronal release of pro-BDNF. Nat Neurosci 12:113-115.

Zuccato C, Ciammola A, Rigamonti D, Leavitt BR, Goffredo D, Conti L, MacDonald ME, Friedlander RM, Silani V, Hayden MR, Timmusk T, Sipione S, Cattaneo E (2001) Loss of huntingtin-mediated BDNF gene transcription in Huntington's disease. Science 293:493-498.

Zuccato C, Tartari M, Crotti A, Goffredo D, Valenza M, Conti L, Cataudella T, Leavitt BR, Hayden MR, Timmusk T, Rigamonti D, Cattaneo E (2003) Huntingtin interacts with REST/NRSF to modulate the transcription of NRSE-controlled neuronal genes. Nat Genet 35:76-83. 